\title{
Emotional and Instrumental Social Support as Determinants of Happiness: A Cross-Sectional Study of Malaysian Elderly
}

Shamsul Azhar Shah ( $\nabla$ drsham@ppukm.ukm.edu.my )

Department of Community Health, Faculty of Medicine, Universiti Kebangsaan Malaysia, 56000 Cheras, Kuala Lumpur, Malaysia

Nazarudin Safian

Department of Community Health, Faculty of Medicine, Universiti Kebangsaan Malaysia, 56000 Cheras, Kuala Lumpur, Malaysia

\section{Saharuddin Ahmad}

Department of Family Medicine, Faculty of Medicine, Universiti Kebangsaan Malaysia, 56000 Cheras, Kuala Lumpur, Malaysia

\section{Wan Abdul Hannan Wan Ibadullah}

Department of Community Health, Faculty of Medicine, Universiti Kebangsaan Malaysia, 56000 Cheras, Kuala Lumpur, Malaysia

\section{Zulkefley Mohammad}

Department of Community Health, Faculty of Medicine, Universiti Kebangsaan Malaysia, 56000 Cheras, Kuala Lumpur, Malaysia

\section{Siti Rohani Nurumal}

Department of Community Health, Faculty of Medicine, Universiti Kebangsaan Malaysia, 56000 Cheras, Kuala Lumpur, Malaysia

\section{Juliana Mansor}

Department of Community Health, Faculty of Medicine, Universiti Kebangsaan Malaysia, 56000 Cheras, Kuala Lumpur, Malaysia

\section{Mohd Fairuz Addnan}

Department of Community Health, Faculty of Medicine, Universiti Kebangsaan Malaysia, 56000 Cheras, Kuala Lumpur, Malaysia

\section{Yugo Shobugawa}

Department of Active Ageing, Niigata University Graduate School of Medical and Dental Sciences, Niigata, 951-8510, Japan

\section{Research Article}

Keywords: Happiness, factor, elderly, Japan Gerontological Evaluation Study 
Posted Date: December 4th, 2020

DOI: https://doi.org/10.21203/rs.3.rs-114263/v1

License: (c) (i) This work is licensed under a Creative Commons Attribution 4.0 International License. Read Full License 


\section{Abstract}

Background: Happiness is an essential component for experience healthy ageing. Hence, understanding the factors that contribute to happiness is essential for a better quality of life. This study aimed to determine the factors associated with happiness among the elderly population in Malaysia.

Methods: In this study, 1204 respondents were recruited from urban and rural areas in Selangor. The faceto-face interview was conducted using the Bahasa Malaysian version of the Japan Gerontological Evaluation Study questionnaire. The inclusion criteria include Malaysians who are 60 years old and above and can converse in the Malaysian language. Those who encounter less than seven scores for the Abbreviated Mental Test were excluded from the study.

Result: Among the 1204 respondents, 953 (79.2\%) of them were happy. In terms of sociodemographic characteristics, men who were happy, 60 to 74 years old and live in urban areas were significantly associated with happiness. Multiple logistic regression analysis showed that the significant factors associated with happiness among the elderly include the social support they receive, both emotional support (adjusted OR 2.33) and instrumental support (adjusted OR 1.59); the locality they reside in (adjusted OR 1.65); how they self-rated themselves in terms of their health status (adjusted OR 1.58); their educational level (adjusted OR 4.20) and their household income (adjusted OR 0.77).

Conclusion: Thus, ensuring the elderly population in receiving emotional and instrumental support can enhance their happiness level.

\section{Background}

As the population of the world is turning into an ageing population, elderly health has become one of the priority aspects (1). This demographic transition will have an impact on all aspects of society. By 2050 , it is estimated that $20 \%$ of the world population will be 60 years or older, amounting to 2 billion people. The 2030 Agenda for Sustainable Development targeted healthy life for all; thus, everyone has the right to health regardless of their age (2). Healthy life involved not only physical health but also mental and social well-being of the person and is not only restricted to the presence of disease or infirmity (3) but also include happiness.

Happiness is an essential factor for healthy ageing (4). It is defined as a positive inner experience that is resulting from an emotional interpretation of their lives and also their individuals' cognitive function (5). The emotional component refers to the pleasure (balance between comfort and pain or unpleasant effect), and the cognitive component is attributed to mental health (6). The term happiness sometimes is interchangeable with life satisfaction. However, life satisfaction is mostly used for the overall happiness. The term happiness is typically used for the affective appraisal of life, and it is synonymous with the hedonic level of effect (7). Steptoe et al. divided subjective well-being into three components, namely 'affective well-being', 'eudaimonic well-being' and 'evaluative well-being'. 
Within this taxonomy, the positive feelings experienced by a person such as happiness and joy were classified as affective well-being. The eudaimonic well-being focus on evaluations of meaning and purpose in life, including personal growth, positive relations with others and self-acceptance. Meanwhile, the evaluative well-being concept is related to the appraisals of how satisfied people are with their quality of life (QOL) (8). Happiness has been used in health literature to denote several different constructs. Steptoe et al. have summarised eight factors that contribute to happiness, namely education, socioeconomic status, social network, time use and activities, stress exposure, marital status and family, personality and genetics (9).

In Malaysia, the study on happiness among the elderly population is less investigated. A study by Boo et al. (10) on the general population of Malaysia with an average age of 40 years noted that most (96\%) of the respondents were happy. The happiness was significantly associated with high household income, employment, high education level and being female. However, it was not significantly associated with age. Meanwhile, a study by Park et al. (11) showed that happiness declined with age in Malaysia and was especially low for those who were 50 years and older. However, there is no known study in Malaysia that focuses on happiness and its associated factors, specifically in the older age group.

Hence, this study aimed to determine the factors associated with happiness among the elderly population in Malaysia focusing on the social engagement and support, education, socioeconomic status, time use and activities, depression status, marital status and family.

\section{Methods}

\section{Study Design}

This was a cross-sectional study conducted among older adults aged 60 years and above in four areas in Selangor, Malaysia. Two rural and two urban areas were selected randomly from the list of housing areas or villages. This study had been ethically approved by the Research Ethics Committee of the National University of Malaysia (FF-2018-532).

The study was conducted from 1 December 2018 to 30 April 2020, involving 1204 respondents who were randomly selected. Respondent information sheets and consent forms were given to the participants after the study has been thoroughly explained. The method of the interview was done in a quiet environment, face-to-face and initiated immediately after the respondents returned the consent forms. The interview was conducted by trained research assistants, ranging from 40 to 50 min to be completed. The study tools use the Bahasa Malaysian version of the Japan Gerontological Evaluation Study (JAGESBM) questionnaire, with the aim to study the determinants of healthy ageing (12). The questionnaire contained multi-dimensional variables, including health factors, psychological factors, functional factors and social determinants of health (supplementary file).

The inclusion criteria are Malaysians who are 60 years old and above and can converse in the Malaysian language. All respondents were screened for the possibility of reduced cognitive function using the 
Abbreviated Mental Test. Those who scored less than 7 were excluded from the study.

\section{Dependent Variable}

The self-perceived happiness was subjectively determined by the respondent using a single question with a scale rated from 0 to 10 points. Thus, it was measured through the following question: To what degree do you feel you are currently happy? (Score ' 0 ' for 'Very unhappy' and ' 10 ' for 'Very happy'). Based on this scale, happiness was defined with a self-rated score of 7-10 points, whereas unhappiness, 0-6 points. This level of the cut points was finalised using the previous survey among the elderly in Japan on their average happiness score, which was 6 points (11).

\section{Covariates}

Sociodemographic variables included age, sex, marital status and location. Age was categorised into the following three categories: $60-74,75-84$ and $\geq 85$ years. On the basis of the article by Steptoe et al., we were able to include five components, namely marital status, socioeconomic, education, social network and physical activities. Marital status was categorised into married living together, married living separately, widowed and divorced and never married. Location was divided into rural and urban.

Socioeconomic status includes household income, education level and current employment status. For household income classification, we were using the Income Structure 2019 by the Department of Statistic Malaysia. B40 refers to the base group or bottom $40 \%$, with a monthly household income of less than RM4,850, whereas M40 refers to the middle-class group or middle $40 \%$, with earnings of between RM4,851 and RM10,959 per month. Conversely, T20 is an upper-class group or top $20 \%$, with monthly earnings of more than RM10,959(12).

In the study, we used social engagement and social support in measuring social network. Social network was measured with the frequency of engagement in group activities. The activities that have been measured were religious, volunteer, sports or club, hobbies, community meetings and political meetings or events. Regular participation of at least once a week is considered active engagement. Meanwhile, social support was measured by asking respondents if they have someone to talk to regarding concerns or complaints (emotional support) and who looked after them when they felt sick and were confined for a few days (instrumental support). These variables were also used by Park et al. in defining social support (10). We also asked if they listen to someone's concerns or complaints and they look after someone when he/she is sick and confined for a few days.

Physical measurement comprises the body mass index (BMI) and handgrip strength (HGS). Weight and height were measured twice for BMI. The Malaysian BMI classification was used as a reference (13), in which underweight is defined as $B M I<18.5 \mathrm{kgm}^{2}$, normal weight is $\mathrm{BMI}=18.5-22.9 \mathrm{~kg} / \mathrm{m}^{2}$, overweight is $\mathrm{BMI} \geq 23 \mathrm{~kg} / \mathrm{m}^{2}$, pre-obese is $\mathrm{BMI}=23.0-27.4 \mathrm{~kg} / \mathrm{m}^{2}$, obese I is $\mathrm{BMI}=27.5-34.9 \mathrm{~kg} / \mathrm{m}^{2}$, obese II 
$\mathrm{BMI}=35.0-39.9 \mathrm{~kg} / \mathrm{m}^{2}$ and obese III is $\mathrm{BMI} \geq 40 \mathrm{~kg} / \mathrm{m}^{2}$. HGS was measured using a handgrip dynamometer with the dominant hand (T.K.K. 5001 GRIP-A from Takei Scientific Instrument Co. Ltd. Japan). Each of the respondents was measured twice, and the mean was taken as reading.

Physical activities for older adults were evaluated through questions regarding the frequency of moderate exertion activities such as brisk walking, golf, dancing, farming, gardening or car washing. This later was translated to an average of 150 min of moderate-intensity aerobic physical activity through the week based on the WHO recommendation (16).

Respondents were asked about self-rated health status who were given four options, namely excellent, good, fair and poor. In addition, we used the Japanese version of the 15-item Geriatric Depression Scale (GDS) to evaluate depressive symptoms in older adults. The GDS score ranges from 0 to 15 , with higher scores that indicate more severe symptoms. The score scale cut points namely those who were having GDS scores of 1-4 as normal, 5-8 as mild depression, 9-11 as moderate depression and $\geq 12$ as severe depression.

Respondents were also asked about the diseases or comorbidity that they have. These include stroke, heart disease, diabetes, hyperlipidemia, respiratory disease, gastrointestinal, liver or gallbladder disease, kidney or prostate gland disease, musculoskeletal disease including osteoporosis and arthritis, traumatic injury, cancer, blood or immune disease, depression, dementia, Parkinson's disease, eye and ear disease, malaria and HIV infection and gynaecological problem.

\section{Data Analyses}

To determine the association among the study variables, chi-square and independent t-test were conducted. Simple logistic regression (SLogR) and multiple logistic regression (MLogR) were used to calculate the crude odds ratio and the adjusted odds ratio, respectively. A p-value of $<0.05$ was considered significant in all tests. Analyses were conducted using IBM SPSS version 21.0 (IBM Corp., Armonk, NY, USA).

\section{Results}

\section{Association of happiness with sociodemographic factors}

Happiness was significantly associated with sociodemographic factors such as age, sex and location, as shown in Table 1. The age which had been divided into three main groups showed that those in the younger age group (60-74 years) were happier than those in the other two groups ( $p=0.031)$. In terms of sex, males were shown to be significantly associated with happiness compared with females $(p=0.031)$. In terms of the locality they reside in, the elderly who lived in urban places were happier in their daily life $(p<0.001)$. 


\section{Association of happiness with socioeconomic status}

Household income has been categorised into three main groups in this study, in which the majority of the respondents were in the B40 group and they had shown to be significantly happier than those in the other two groups. In the same group, those who are currently employed were regarded to be happier than those in the other two groups, although the difference was not statistically significant.

Table 1 Sociodemographic characteristics of respondents 


\begin{tabular}{|c|c|c|c|c|c|}
\hline \multirow[t]{2}{*}{ Variables } & \multirow[t]{2}{*}{$\mathbf{N}$} & \multirow[t]{2}{*}{ (\%) } & \multicolumn{2}{|c|}{ Happiness, N (\%) } & \multirow[t]{2}{*}{ p-value } \\
\hline & & & Happy & Unhappy & \\
\hline \multicolumn{6}{|l|}{ Age group } \\
\hline Young old (60-74 years) & 996 & 82.7 & $801(80.4)$ & $195(19.6)$ & 0.031 \\
\hline Middle old (75-84 years) & 186 & 15.4 & $138(74.2)$ & $48(25.8)$ & \\
\hline Old old ( $\geq 85$ years) & 22 & 1.8 & $14(63.6)$ & $8(36.4)$ & \\
\hline \multicolumn{6}{|l|}{ Sex } \\
\hline Male & 691 & 57.4 & $562(81.3)$ & $129(18.7)$ & 0.031 \\
\hline Female & 513 & 42.6 & $391(76.2)$ & $122(23.8)$ & \\
\hline \multicolumn{6}{|l|}{ Marital status } \\
\hline Married (living together) & 790 & 65.6 & $644(81.5)$ & $146(18.5)$ & 0.049 \\
\hline Married (living separately) & 12 & 1.0 & $9(75.0)$ & $3(25.0)$ & \\
\hline Widowed or divorced & 384 & 1.8 & $287(74.7)$ & $97(25.3)$ & \\
\hline Never married & 18 & 1.5 & $13(72.2)$ & $5(27.8)$ & \\
\hline \multicolumn{6}{|l|}{ Household composition } \\
\hline Stay alone & 64 & 5.3 & $54(84.4)$ & $10(15.6)$ & 0.253 \\
\hline Stay with blood-related family & 1134 & 94.2 & $893(78.7)$ & $241(21.3)$ & \\
\hline Stay with other family (non-blood-related) & 6 & 0.5 & $6(100.0)$ & $0(0)$ & \\
\hline \multicolumn{6}{|l|}{ Location } \\
\hline Rural & 602 & 50.0 & $450(74.8)$ & $152(25.2)$ & $<0.001$ \\
\hline Urban & 602 & 50.0 & $503(83.6)$ & $99(16.4)$ & \\
\hline \multicolumn{6}{|l|}{ Education level } \\
\hline Primary or less & 665 & 55.2 & $513(77.1)$ & $152(22.9)$ & 0.035 \\
\hline Secondary & 426 & 35.4 & $341(80.0)$ & $85(20.0)$ & \\
\hline Tertiary & 113 & 9.4 & $99(87.6)$ & $14(12.4)$ & \\
\hline \multicolumn{6}{|l|}{ Current employment status } \\
\hline Employed & 169 & 14.0 & $139(82.2)$ & $30(17.8)$ & 0.560 \\
\hline Retired from job & 868 & 72.1 & $682(78.6)$ & $186(21.4)$ & \\
\hline Never had a job & 167 & 13.9 & $132(79.0)$ & $35(21.0)$ & \\
\hline
\end{tabular}




\begin{tabular}{|llllll|}
\hline Household income & & & & & \\
\hline B40 & 1094 & 90.9 & $851(77.8)$ & $243(22.2)$ & 0.001 \\
\hline M40 & 98 & 8.1 & $91(92.9)$ & $7(7.1)$ & \\
\hline T20 & 12 & 1.0 & $11(91.7)$ & $1(8.3)$ \\
\hline
\end{tabular}

\section{Association of happiness with health parameters}

Happiness was significantly associated with health parameters such as moderate physical activity, selfrated health status, comorbidity, GDS and HGS as shown in Table 2. The study revealed that the relationship between self-rated health status and happiness was significant $(p=<0.001)$. Those who have fair and poor health status had a lower prevalence of happiness than those who have excellent and good health status as shown in Table 2 . Meanwhile, BMI was not significantly associated with happiness. In terms of the presence of chronic diseases or comorbidity, those who do not have comorbidity has a significantly higher prevalence of happiness $(p=0.042)$. The study also showed that unhappy participants had significantly higher GDS (mean $=3.4, S D=2.51$ ) than happy participants. Meanwhile, for HGS measurement, those who were happy demonstrated higher HGS (mean $=26.0 \mathrm{~kg}$, $S D=8.61)$ than those who were unhappy.

Table 2 The association between health parameters and happiness status 


\begin{tabular}{|c|c|c|c|c|c|}
\hline \multirow[t]{2}{*}{ Variables } & \multirow[t]{2}{*}{$\mathbf{N}$} & \multirow[t]{2}{*}{ (\%) } & \multicolumn{2}{|c|}{ Happiness, N (\%) } & \multirow[t]{2}{*}{$\chi 2$ test $(p)$} \\
\hline & & & Happy & Unhappy & \\
\hline \multicolumn{6}{|l|}{ Physical activity } \\
\hline Yes & 632 & 52.5 & $516(81.6)$ & $116(18.4)$ & $5.01,(p=0.025)$ \\
\hline No & 572 & 47.5 & $437(76.4)$ & $135(23.6)$ & \\
\hline \multicolumn{6}{|l|}{ Self-rated health status } \\
\hline Excellent & 44 & 3.7 & $37(84.1)$ & $7(15.9)$ & $23.39,(p<0.001)$ \\
\hline Good & 668 & 55.5 & $560(83.8)$ & $108(16.2)$ & \\
\hline Fair & 441 & 36.6 & $320(72.6)$ & $121(27.4)$ & \\
\hline Poor & 51 & 4.2 & $36(70.6)$ & $15(29.4)$ & \\
\hline \multicolumn{6}{|l|}{ BMI class $^{1}$} \\
\hline Normal & 223 & 18.5 & $167(74.9)$ & $56(25.1)$ & $8.219(p=0.145)$ \\
\hline Obese I & 410 & 34.1 & $329(80.2)$ & $81(19.8)$ & \\
\hline Obese II & 61 & 5.1 & $44(72.1)$ & $17(27.9)$ & \\
\hline Obese III & 17 & 1.4 & $15(88.2)$ & $2(11.8)$ & \\
\hline Pre-obese & 454 & 37.7 & $370(81.5)$ & $84(18.5)$ & \\
\hline Underweight & 39 & 3.2 & $28(71.8)$ & $11(28.2)$ & \\
\hline \multicolumn{6}{|l|}{ Comorbidity } \\
\hline Yes & 941 & 78.2 & $733(77.9)$ & $208(22.1)$ & $4.125,(p=0.042)$ \\
\hline No & 263 & 21.8 & $220(83.7)$ & $45(16.3)$ & \\
\hline \multicolumn{6}{|c|}{ General Depression Score (GDS) } \\
\hline No depression & 1052 & 87.4 & $859(81.7)$ & 193(18.3) & 46.706, $(p<0.001)$ \\
\hline Mild depression & 133 & 11.0 & $88(66.2)$ & 45(33.8) & \\
\hline Moderate depression & 15 & 1.2 & $6(40.0)$ & $9(60.0)$ & \\
\hline Severe depression & 4 & 0.4 & $0(0.0)$ & $4(100.0)$ & \\
\hline Mean (SD) & & & $2.5(1.66)$ & $3.4(2.51)$ & $t=5.827,(p<0.001)$ \\
\hline \multicolumn{6}{|l|}{ Handgrip strength (HGS) } \\
\hline Mean (SD) in kilograms & & & $26.0(8.61)$ & $23.5(7.89)$ & $t=4.422,(P<0.001)$ \\
\hline
\end{tabular}




\section{Association of happiness with social network}

Most of the respondents had engaged with social group activities as shown in Table 3 . Only $17.9 \%$ of them were not involved with any kind of group activity. Frequent engagement in social activity was significantly associated with happiness $(p=<0.001)$. The majority of them $(60.6 \%)$ engaged with religious group activities, followed by community meetings $(9.6 \%)$, hobbies $(5.8 \%)$, political meetings or events $(2.6 \%)$, sports or clubs $(2.0 \%)$ and volunteer group activities $(1.6 \%)$.

Most of the respondents received and acted as providers for social support. However, those who have someone to talk to regarding their concerns and problems $(p=0.002)$ and have someone to look after them when they are sick $(p=0.031)$ were significantly associated with happiness. The main person who was accountable for providing emotional support for the respondents was their spouse (50.2\%). Conversely, the main persons that provide instrumental support for the respondents were their children who are living with them (56.5\%).

Table 3 The association between social network and happiness

\begin{tabular}{|c|c|c|c|c|c|}
\hline \multicolumn{2}{|c|}{ Social engagement } & \multirow[t]{2}{*}{$N(\%)$} & \multicolumn{2}{|c|}{ Happiness, N (\%) } & \multirow[t]{2}{*}{$\chi 2$ test $(p)$} \\
\hline & & & Happy & Unhappy & \\
\hline \multicolumn{2}{|l|}{ Active } & $687(57.1)$ & $574(83.6)$ & $113(16.4)$ & $22.97(<0.001)$ \\
\hline \multicolumn{2}{|l|}{ Less active } & $301(25.0)$ & $230(76.4)$ & $71(23.6)$ & \\
\hline \multicolumn{2}{|l|}{ Never } & $216(17.9)$ & $149(69.0)$ & $67(31.0)$ & \\
\hline \multirow{2}{*}{\multicolumn{2}{|c|}{ Receiving social support }} & $\mathbf{N}(\%)$ & \multicolumn{2}{|c|}{ Happiness, N (\%) } & $\chi 2$ test $(p)$ \\
\hline & & & Happy & Unhappy & \\
\hline \multirow[t]{2}{*}{ Emotional } & Yes & $1126(93.5)$ & $902(80.1)$ & $224(19.9)$ & $9.581(0.002)$ \\
\hline & No & $78(6.5)$ & $51(65.4)$ & $48(34.6)$ & \\
\hline \multirow[t]{2}{*}{ Instrumental } & Yes & $1117(92.8)$ & $892(79.9)$ & $225(20.1)$ & $4.642(0.031)$ \\
\hline & No & $87(7.2)$ & $61(70.1)$ & $26(26.9)$ & \\
\hline \multirow{2}{*}{\multicolumn{2}{|c|}{ Providing social support }} & $\mathbf{N}(\%)$ & \multicolumn{2}{|c|}{ Happiness, N (\%) } & $\chi 2$ test $(p)$ \\
\hline & & & Happy & Unhappy & \\
\hline \multirow[t]{2}{*}{ Emotional } & Yes & $1080(89.7)$ & $860(79.6)$ & $220(20.4)$ & $1.445(0.229)$ \\
\hline & No & $124(10.3)$ & $93(75.0)$ & $31(25.0)$ & \\
\hline \multirow[t]{2}{*}{ Instrumental } & Yes & $982(81.6)$ & $783(79.7)$ & $199(20.3)$ & $1.095(0.295)$ \\
\hline & No & $222(18.4)$ & 170 (76.6) & $52(23.4)$ & \\
\hline
\end{tabular}




\section{Bivariate and Multivariable analysis}

Crude OR and Adjusted OR were obtained using SLogR and MLogR, respectively, as shown in Table 4. There were only six variables included in the final model, namely locality, educational level, household income, self-rated health status and social support both in terms of emotional and instrumental support.

Table 4 Simple logistic regression and multiple logistic regression between variables and happiness 


\begin{tabular}{|c|c|c|c|c|c|c|c|}
\hline & & SLog $\mathrm{R}^{\mathrm{a}}$ & & & $M L o g R^{b}$ & & \\
\hline Variable & & $\begin{array}{l}\text { Crude } \\
\text { OR }\end{array}$ & $\begin{array}{l}95 \% \mathrm{Cl} \\
\text { OR }\end{array}$ & $\begin{array}{l}\chi 2 \text { test } \\
(\mathrm{p}- \\
\text { value })\end{array}$ & $\begin{array}{l}\text { Adjusted } \\
\text { OR }\end{array}$ & $\begin{array}{l}95 \% \mathrm{Cl} \\
\text { OR }\end{array}$ & $\begin{array}{l}x 2 \text { test } \\
(p- \\
\text { value })\end{array}$ \\
\hline \multicolumn{8}{|l|}{ Age group } \\
\hline & Young old & 1.00 & & & - & - & - \\
\hline & Middle old & 0.43 & $\begin{array}{l}(0.176, \\
1.030)\end{array}$ & $\begin{array}{l}3.59 \\
(0.058)\end{array}$ & - & - & - \\
\hline & Old old & 0.61 & $\begin{array}{l}(0.240, \\
1.541)\end{array}$ & $\begin{array}{l}1.098 \\
(0.295)\end{array}$ & - & - & - \\
\hline \multicolumn{8}{|l|}{ Sex } \\
\hline & Male & 1.00 & & & - & - & - \\
\hline & Female & 0.74 & $\begin{array}{l}(0.556, \\
0.973)\end{array}$ & $\begin{array}{l}4.65 \\
(0.031)\end{array}$ & - & - & - \\
\hline \multicolumn{8}{|l|}{ Marital status } \\
\hline & $\begin{array}{l}\text { Married } \\
\text { (living } \\
\text { together) }\end{array}$ & 1.00 & & & - & - & - \\
\hline & $\begin{array}{l}\text { Married } \\
\text { (living } \\
\text { separately) }\end{array}$ & 0.589 & $\begin{array}{l}(0.207, \\
1.679)\end{array}$ & $\begin{array}{l}0.98 \\
(0.322)\end{array}$ & - & - & - \\
\hline & $\begin{array}{l}\text { Widowed } \\
\text { and divorced }\end{array}$ & 0.867 & $\begin{array}{l}(0.164, \\
4.579)\end{array}$ & $\begin{array}{l}0.03 \\
(0.866)\end{array}$ & - & - & - \\
\hline & $\begin{array}{l}\text { Never } \\
\text { married }\end{array}$ & 0.879 & $\begin{array}{l}(0.305, \\
2.528)\end{array}$ & $\begin{array}{l}0.06 \\
(0.811)\end{array}$ & - & - & - \\
\hline \multicolumn{8}{|l|}{ Locality } \\
\hline & Urban & 0.583 & $\begin{array}{l}(0.439, \\
0.774)\end{array}$ & $\begin{array}{l}13.964 \\
(<0.001)\end{array}$ & 1.65 & $\begin{array}{l}(1.189, \\
2.290)\end{array}$ & $\begin{array}{l}8.97 \\
(0.003)\end{array}$ \\
\hline & Rural & 1.00 & & & & & \\
\hline \multirow[t]{4}{*}{ Education level } & & & & & & & $\begin{array}{l}11.68 \\
(0.003)\end{array}$ \\
\hline & $\begin{array}{l}\text { Primary or } \\
\text { less }\end{array}$ & 1.00 & & & & & \\
\hline & Secondary & 0.84 & $\begin{array}{l}(0.624, \\
1.134)\end{array}$ & $\begin{array}{l}1.29 \\
(0.257)\end{array}$ & 4.20 & $\begin{array}{l}\text { (1.585, } \\
11.119)\end{array}$ & $\begin{array}{l}8.33 \\
(0.004)\end{array}$ \\
\hline & Tertiary & 0.48 & $\begin{array}{l}(0.265, \\
0.859)\end{array}$ & $\begin{array}{l}6.08 \\
(0.014)\end{array}$ & 15.37 & $\begin{array}{l}(0.089 \\
265.592)\end{array}$ & $\begin{array}{l}3.53 \\
(0.060)\end{array}$ \\
\hline
\end{tabular}




\begin{tabular}{|c|c|c|c|c|c|c|}
\hline B40 & 1.00 & & & & & \\
\hline M40 & 0.27 & $\begin{array}{l}(0.123, \\
0.589)\end{array}$ & $\begin{array}{l}10.81 \\
(0.001)\end{array}$ & 0.32 & $\begin{array}{l}(0.135, \\
0.770)\end{array}$ & $\begin{array}{l}6.49 \\
(0.011)\end{array}$ \\
\hline T20 & 0.32 & $\begin{array}{l}(0.0411, \\
2.478)\end{array}$ & $\begin{array}{l}1.20 \\
(0.318)\end{array}$ & 0.77 & $\begin{array}{l}(0.089, \\
6.633)\end{array}$ & $\begin{array}{l}0.057 \\
(0.811)\end{array}$ \\
\hline
\end{tabular}

Physical activity

\begin{tabular}{|c|c|c|c|c|c|c|c|}
\hline & No & 0.73 & $\begin{array}{l}(0.551 \\
0.962)\end{array}$ & $\begin{array}{l}4.99 \\
(0.026)\end{array}$ & & & \\
\hline & Yes & 1.00 & & & & & \\
\hline \multirow[t]{5}{*}{$\begin{array}{l}\text { Self-rated health } \\
\text { status }\end{array}$} & & & & & & & $\begin{array}{l}12.79 \\
(0.005)\end{array}$ \\
\hline & Excellent & 0.45 & $\begin{array}{l}(0.166, \\
1.244)\end{array}$ & $\begin{array}{l}2.36 \\
(0.125)\end{array}$ & 0.89 & $\begin{array}{l}(0.299, \\
2.630)\end{array}$ & $\begin{array}{l}0.05 \\
(0.828)\end{array}$ \\
\hline & Good & 0.46 & $\begin{array}{l}(0.245, \\
0.875)\end{array}$ & $\begin{array}{l}5.63 \\
(0.018)\end{array}$ & 0.91 & $\begin{array}{l}(0.443, \\
1.855)\end{array}$ & $\begin{array}{l}0.07 \\
(0.788)\end{array}$ \\
\hline & Fair & 0.91 & $\begin{array}{l}(0.480 \\
1.717)\end{array}$ & $\begin{array}{l}0.09 \\
(0.765)\end{array}$ & 1.58 & $\begin{array}{l}(0.774, \\
3.212)\end{array}$ & $\begin{array}{l}1.57 \\
(0.210)\end{array}$ \\
\hline & Poor & 1.00 & & & & & \\
\hline
\end{tabular}

\section{Comorbidity}

\begin{tabular}{llll} 
No & 1.45 & $\begin{array}{l}(1.012, \\
2.084)\end{array}$ & $\begin{array}{l}4.09 \\
(0.043)\end{array}$ \\
\hline Yes & 1.00 & & \\
\hline
\end{tabular}

\section{General}

Depression

Score (GDS)

\begin{tabular}{|c|c|c|c|c|c|c|c|}
\hline & $\begin{array}{l}\text { No } \\
\text { depression }\end{array}$ & 1.00 & & & & & \\
\hline & $\begin{array}{l}\text { Mild } \\
\text { depression }\end{array}$ & 2.28 & $\begin{array}{l}(1.538, \\
3.367)\end{array}$ & $\begin{array}{l}16.94 \\
(<0.001)\end{array}$ & - & - & - \\
\hline & $\begin{array}{l}\text { Moderate } \\
\text { depression }\end{array}$ & 6.68 & $\begin{array}{l}\text { (2.349, } \\
19.978)\end{array}$ & $\begin{array}{l}12.69 \\
(<0.001)\end{array}$ & - & - & - \\
\hline & $\begin{array}{l}\text { Severe } \\
\text { depression }\end{array}$ & 71901 & $(0.000)$, & $\begin{array}{l}0.00 \\
(0.999)\end{array}$ & - & - & - \\
\hline $\begin{array}{l}\text { Handgrip } \\
\text { strength (HGS) }\end{array}$ & & 0.965 & $\begin{array}{l}(0.949, \\
0.982)\end{array}$ & $\begin{array}{l}16.68 \\
(<0.001)\end{array}$ & - & - & - \\
\hline
\end{tabular}




\section{Social}

engagement

$\begin{array}{llll}\text { Never } & 1.00 & & \\ \text { Less active } & 1.57 & (1.123, & \begin{array}{l}6.97 \\ (0.008)\end{array} \\ & & 2.190) & \\ \text { Active } & 2.28 & (1.607, & \begin{array}{l}21.17 \\ (<0.001)\end{array}\end{array}$

\section{Social support}

Emotional

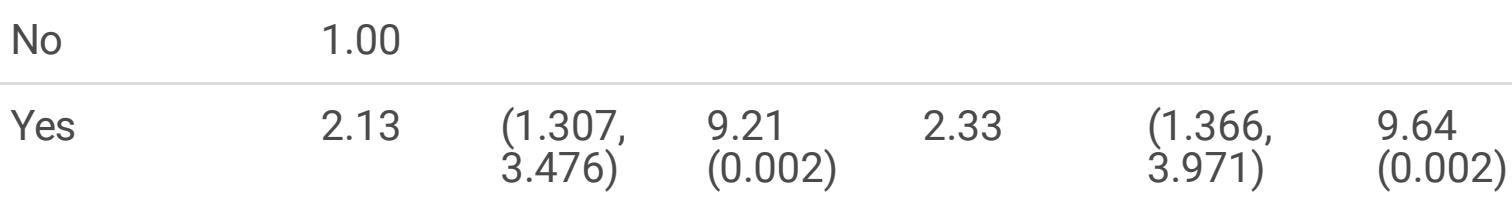

Instrumental

$\begin{array}{lllllll}\text { No } & 1.00 & & & & & \\ \text { Yes } & 1.69 & (1.044, & 4.55 & 1.59 & (0.936, & 2.947 \\ & & 2.736) & (0.033) & & 2.708) & (0.086)\end{array}$

Notes: a Simple logistic regression. ${ }^{b}$ Multiple logistic regression (Nagelkerke $\mathrm{R}^{2}=0.163$ ); this model fits well (Hosmer-Lemesler test, $p=0.741)$; model assumptions are met; there are interactions between educational level and sex, handgrip strength and social engagement); however, no multicollinearity problem was found.

In terms of locality, those living in urban areas are almost two times happier than those living in rural areas. For educational level, those who have secondary level of education were almost five times happier, and those who obtained tertiary level of education are 15 times happier than the rest of the groups. Regarding household income, those in the M40 groups would significantly have $68 \%$ odds of being unhappy, whereas those in the T20 groups would have $23 \%$ odds of being unhappy; however, it was not significantly associated with happiness.

Among those who self-rated themselves as having fair health status, they are almost two times happier than those in the other groups. However, those who rated themselves as having excellent health status and good health status would have the odds of $11 \%$ and $9 \%$ of being unhappy, respectively. However, those with excellent health status was not significantly associated with happiness. Lastly, compared with those who did not receive both of the social support, those who receive emotional support were two times 
happier, and those who receive instrumental support were also almost two times happier. This final model explains a $16.3 \%$ variation of happiness in the study $R^{2}=0.163$.

\section{Discussion}

The findings of this study showed that $79.2 \%$ of the elderly who participated in the study were happy and the factors that contributed to their happiness were significantly associated with the social support they received, which include both emotional and instrumental support, the location they reside in, the educational level they attained, the household income they receive monthly and how they self-rated their health status themselves. Comparatively, the JAGES-BM conducted in Japan involving Japanese older adults aged 65 years and above showed that $68 \%$ of them were happy (17). The percentage of happiness is slightly lower than that in Malaysian elderly based on our study. With greater life expectancy in Japan for both men and women, the elderly are prone to loneliness and social isolation. The famous Japanese word 'kodokushi, which refers to dying alone with the corpse that remained undiscovered for a long period of time, commonly makes Japanese elderly anxious as they aged(18). This might contribute to the lower percentage of happiness among Japanese elderly than among Malaysian elderly. Peer-based intervention as one of the methods to overcome loneliness and social isolation among the elderly has been proven to enhance happiness among them(19).

This study showed that happiness is significantly associated with younger-age elderly. This similar finding is also revealed in recent studies conducted in Iran (20) and Brazil (21). The positive relationship between young old (60-74 years) and happiness can be explained to be due to financial stability and healthier status among this age group. Furthermore, this can be explained by the rationale that men are happier as they are recognised in the local community as the breadwinner of the family and thus will be having more financial freedom at the later stage of their life. However, in Japan, elderly women were happier than elderly men (13), and this could be explained by the collectivist value relatedness of the Japanese people, by which Japanese women who respect relatedness might be considered adaptable to live under collectivistic cultures (22).

In terms of location, the elderly living in urban areas are happier. This is similar to the finding in the previous study conducted at Chonburi Province, Thailand, as they can have access to some hobbies or activities. The elderly living in urban areas receive regular monthly retirement pension, whereas those in rural areas still have to work at an advanced age as they only have subsistence allowance (23).

As mentioned above, household income is associated with happiness. In general, the higher-income person is happier than the lower-income one. However, in the multivariable analysis, the highest household income (T20) was not significantly associated with happiness level. Having enough money will allow one to fulfil his/her material needs, thus affecting his/her happiness. By contrast, having excess income beyond the needs will not affect happiness (24). The low socioeconomic status is of critical importance for older people and directly affects their mental health and subsequently increase the risk for suicidal ideation (25). A Korean national-level study noted that household income is associated 
with interpersonal trust and depressive symptoms (26)(27). In this study, the less depressive a person is, the happier he/she is. A study noted that adjusting for depression and pension types have an effect on happiness status (13). However, a Brazilian study involving 236 people found no association between household income and happiness (21).

In addition, education level contributes to happiness level. A study in Singapore and Iran noted that those with higher education levels are more likely to be happy (28)(24), which is similar to our findings. This might be due to that highly educated people tend to have better jobs during the working phase and thus have better earnings than those with low education levels (29). In addition, knowledge allows an individual to seek ways to ensure his/her happiness, hence leading to successful ageing (30). Although, in this study, sex is not associated with happiness level, a study in Taiwan revealed that education level only affects the female respondents (31), possibly because the happiness level of male respondents was critically determined by other factors such as physical activity and income level instead of education level (32). However, education could have no association with happiness as observed by Wen et al. (33).

In terms of health parameters, this study showed that older people who rated themselves as good is significantly associated with happiness. Meanwhile, those who rated themselves as having excellent health status is not significantly associated with happiness. This could be because, for them, the selfrated health status between good and excellent has the same meaning. In addition, the proportion of excellent health status in the study is too small, i.e. 3.7\%. A study conducted in the United States involving African-American men showed that those who were happy have $60 \%$ lower odds of rating their physical health as fair or poor (34). Based on the result of this study, not having comorbidities and depression has shown a significant association with being happier compared with having any chronic diseases and depression. A similar result was shown in one of the studies conducted among older Korean women living alone to determine the predictors of their happiness. The study found that happiness was negatively correlated with the number of comorbidities and having depressive symptoms (35). In terms of HGS, the higher the score of HGS, the happier they are, compared with those with lower scores in HGS measurement. This is consistent with a study conducted among male university students at British University, which showed that HGS correlated significantly $(r=0.43)$ with how they perceived themselves as being happy (36).

Considering social support, older people receiving emotional and instrumental support showed a more positive view of happiness, and this was similar to that shown in the studies in Iran and Japan $(20,37)$. Older people who received social support felt appreciated and have a higher level of satisfaction and QOL than those who do not receive social support (38). Meanwhile, the present study showed that providing social support was not significantly associated with happiness, and this was in contrast to a study conducted in Japan (37). Providing social support could increase their self-confidence and self-esteem and subsequently increase the happiness level. However, some people who were providing social support may perceive or receive the task as a burden (39). In 2018, a study was conducted in Thailand to see the factors that affect the QOL among the elderly population showed that emotional support did contribute significantly to improving the QOL of elderly people(40). 
A cross-sectional study conducted in Thailand among 233 elderly women aged $60-80$ years yielded that more than half of them were happy and the social support and family relationship could predict $91 \%$ of their happiness level (41). Recently, a similar study conducted in Qazvin City, Iran, involving 312 elderly people showed that there is a significant and positive relationship between happiness and social support they receive particularly from their family and friends (42). This finding strengthens the fact that social support plays crucial roles for elderly people towards achieving healthy ageing. Social support does contribute significantly to the happiness level among the elderly as evidenced by the finding in a crosssectional study conducted involving Spanish men and women. It was recommended that the provision of more social support may increase older peoples' happiness in later life towards achieving healthy ageing (43). A similar recommendation was made based on a study conducted in Japan that explored the critical factors of happiness among middle-aged Japanese people, urging the government to have extended social services and policymaking towards making the people happier (22). The lack of social support has been proven to be associated with increased psychological distress especially among older people by a study conducted in Norway (44).

This study has its own limitations. The older people are not a homogeneous group of frail individuals who progress rapidly towards disease and need of care. Successful and healthy ageing can also be determined by their personality traits, which were not explored in this study. According to Kahlbaugh et al. to have successful ageing, being open and teachable and having low neuroticism are important (45). Therefore, the personality traits of each elderly individual would be additional factors that might contribute to their happiness level. Second, some of the questions such as those about self-rated health status are considered to be based on the participants' perception, but there are no confirmatory questions and tests to support this.

When considering who shall provide social support for the elderly, family members are the first to be thought of. Hence, more awareness programmes must be initiated among family members regarding social support for their elderly. However, there are several circumstances in which family members cannot provide support; hence, having various sources of social support is essential. Community-based services are useful for the elderly especially for those who are living alone. Support for the elderly can be found in several places including assisted living facilities, homes or care centres for the elderly, meal delivery or even religious affiliations. These services can provide positive social support, either emotional or instrumental, which can help the elderly defeat loneliness and isolation.

\section{Conclusion}

To conclude, for the benefit of the next generation of older people, emotional and instrumental support among them should be assured to promote lifelong happiness. Therefore, programmes or activities should be structured and established with the aim of strengthening the social support in the elderly population.

\section{Abbreviations}


JAGES-BM: the Bahasa Malaysian version of the Japan gerontological evaluation study; HGS: handgrip strength; NCD: non-communicable diseases; SLogR: simple logistic regression; MLogR: multiple logistic regression; BMI: body mass index; B40: bottom 40\%; M40: middle 40\%; T20: top 20\%; GDS: Geriatric Depression Scale.

\section{Declarations}

\section{Ethics approval}

This study was conducted in line with the principles of the Declaration of Helsinki. The present study has been ethically approved by the Research Ethics Committee of Universiti Kebangsaan Malaysia (UKM) (FF2018-532). Participants have been informed regarding the content of the study, and all participants provided written consent.

\section{Consent for publication}

Not applicable.

\section{Availability of data and materials}

The research datasets analysed during the current study are available in the Mendeley dataset repository. [http://dx.doi.org/10.17632/t5nb6g859m.1].

\section{Competing interest}

The authors declare no conflicts of interest.

\section{Funding}

The present study is funded by the World Health Organization Centre for Health Development (WHO Kobe Centre-WKC)

\section{Authors' contributions}

Shamsul Azhar Shah conceptualised the study and supervised all aspects of its implementation. Wan Abdul Hannan Wan Ibadullah and Siti Rohani Nurumal completed the statistical analyses and led the writing of the manuscript. Nazarudin Safian, Saharuddin Ahmad, Zulkefley bin Mohammad and Juliana Mansor assisted in conducting the study and in analysing the data. Yugo Shobugawa and Mohd Fairuz Addnan assisted in critical revision. All authors contributed to conceptualising ideas, interpreting findings, and reviewing the drafts of the manuscript, and they approved the final version of the manuscript.

\section{Acknowledgements}

We are grateful to the personnel of the Department of Community Health, Faculty of Medicine Universiti Kebangsaan Malaysia, for their assistance in the survey. We also appreciate the heads of the respective 
residential areas in Selangor for their cooperation and assistance.

\section{References}

1. World Health Organization. Global strategy and action plan on ageing and health. Geneva; 2017.

2. Department of Economic and Social Affairs U. Transforming our world: the 2030 Agenda for Sustainable Development. United Nations. 2015.

3. World Health Organization W. Constitution of the World Health Organization. Am J Public Health Nations Health. 1946;36(11):1315-23.

4. Bum $\mathrm{CH}$, Johnson JA, Choi $\mathrm{C}$. Healthy aging and happiness in the korean elderly based upon leisure activity type. Iran J Public Health. 2020;49(3):454-62.

5. Diener E, Oishi S, Lucas RE. Personality, Culture, and Subjective Well-being: Emotional and Cognitive Evaluations of Life. Annu Rev Psychol. 2003;54:403-25.

6. Cohen S, Herbert TB. Health Psychology: Psychological Factors and Physical Disease from the Perspective of Human Psychoneuroimmunology. Annu Rev Psychol. 1996;47:113-42.

7. Veenhoven R. Happiness: Also known as 'life-satisfaction' and 'subjective well-being.' Handbook of Social Indicators and Quality of Life Research. 2012. 1-593 p.

8. Steptoe A, Deaton A, Stone AA. Subjective wellbeing, health, and ageing. Vol. 385, The Lancet. Lancet Publishing Group; 2015. p. 640-8.

9. Steptoe A. Happiness and Health. Annu Rev Public Health. 2019;40:339-59.

10. Boo MC, Yen SH, Lim HE. A note on happiness and life satisfaction in Malaysia. Malaysian J Econ Stud. 2016;53(2):261-77.

11. Park MSA, Joshanloo M. Satisfaction with Life Declines with Age in Malaysia: an Exploratory Analysis of Factors Influencing Subjective Well-Being in a Developing/Middle-Income Country. Appl Res Qual Life. 2019;

12. Kondo K. Progress in aging epidemiology in Japan: The JAGES project. J Epidemiol [Internet]. 2016 [cited 2020 Nov 21];26(7):331-6. Available from: https://pubmed.ncbi.nlm.nih.gov/27349200/

13. Sasaki I, Kondo K, Kondo N, Aida J, Ichikawa H, Kusumi T, et al. Are pension types associated with happiness in Japanese older people?: JAGES cross-sectional study. PLoS One. 2018;13(5):1-14.

14. DOSM. Quarter 4 2019. 2020.

15. Alamuddin N, Bakizada Z, Wadden TA. Management of obesity. J Clin Oncol. 2016;34(35):4295305.

16. World Health Organization. Global recommendations on physical activity for health: 65 years and above. Geneva World Heal Organ. 2011;60.

17. Sasaki I, Kondo K, Kondo N, Aida J, Ichikawa H, Kusumi T, et al. Are pension types associated with happiness in Japanese older people?: JAGES cross-sectional study. Bayer A, editor. PLoS One. 2018 May;13(5):e0197423. 
18. Suzuki K, Dollery BE, Kortt MA. Addressing loneliness and social isolation amongst elderly people through local co-production in Japan. Soc Policy Adm [Internet]. 2020 Sep 4 [cited 2020 Oct 22];spol.12650. Available from: https://onlinelibrary.wiley.com/doi/abs/10.1111/spol.12650

19. Lai DWL, Li J, Ou X, Li CYP. Effectiveness of a peer-based intervention on loneliness and social isolation of older Chinese immigrants in Canada: a randomized controlled trial. BMC Geriatr [Internet]. 2020 Sep 21 [cited 2020 Oct 23];20(1):356. Available from: https://bmcgeriatr.biomedcentral.com/articles/10.1186/s12877-020-01756-9

20. Moeini B, Barati M, Farhadian M, Ara MH. The association between social support and happiness among elderly in Iran. Korean J Fam Med. 2018;39(4):260-5.

21. Luchesi BM, de Oliveira NA, de Morais D, de Paula Pessoa RM, Pavarini SCl, Chagas MHN. Factors associated with happiness in the elderly persons living in the community. Arch Gerontol Geriatr. 2018;74(August 2017):83-7.

22. Moriyama Y, Tamiya N, Kawachi N, Miyairi M. What Makes Super-Aged Nations Happier? Exploring Critical Factors of Happiness Among Middle-Aged Men and Women in Japan. World Med Heal Policy. 2018;10(1):83-98.

23. Sumngern C, Azeredo Z, Subgranon R, Sungvorawongphana N, Matos E. Happiness among the elderly in communities: A study in senior clubs of Chonburi Province, Thailand. Japan J Nurs Sci. 2010;7(1):47-54.

24. Moeini B, Barati M, Farhadian M, Babamiri M, Heydari Ara M. Happiness and Its Related Factors among the Elderly in Hamadan (Iran): A Cross Sectional Study. Avicenna J Neuro Psycho Physiol. 2016 Nov;3(4):57782.

25. Ju YJ, Park EC, Han KT, Choi JW, Kim JL, Cho KH, et al. Low socioeconomic status and suicidal ideation among elderly individuals. Int Psychogeriatrics. 2016;28(12):2055-66.

26. Han KM, Han C, Shin C, Jee HJ, An H, Yoon HK, et al. Social capital, socioeconomic status, and depression in community-living elderly. J Psychiatr Res. 2018 Mar;98:133-40.

27. Song A, Kim W. The association between relative income and depressive symptoms in adults: Findings from a nationwide survey in Korea. J Affect Disord. 2020 Feb;263:236-40.

28. Tan JH, Abdin E, Shahwan S, Zhang Y, Sambasivam R, Vaingankar JA, et al. Happiness and cognitive impairment among older adults: Investigating the mediational roles of disability, depression, social contact frequency, and loneliness. Int J Environ Res Public Health. 2019;16(24).

29. Mohamad Yunus N. Returns From Higher Education in Malaysia: Analysis of Wage-Employed and Self-Employed Workers. Vol. 12, International Journal of Economics and Management Journal homepage. 2018.

30. Tkatch R, Musich S, MacLeod S, Kraemer S, Hawkins K, Wicker ER, et al. A qualitative study to examine older adults' perceptions of health: Keys to aging successfully. Geriatr Nurs (Minneap). 2017 Nov;38(6):485-90.

31. Lin YT, Chen MC, Ho CC, Lee TS. Relationships among leisure physical activity, sedentary lifestyle, physical fitness, and happiness in adults 65 years or older in Taiwan. Int J Environ Res Public Health. 
2020;17(14):1-12.

32. Striessnig E, Lutz W. Too Educated to be Happy? An Investigation into the Relationship between Education and Subjective Well-being. Laxenburg; 2015.

33. Wen M, Ren Q, Korinek K, Trinh HN. Living in skipped generation households and happiness among middle-aged and older grandparents in China. Soc Sci Res. 2019;80(December 2017):145-55.

34. Mwinnyaa G, Porch T, Bowie J, Thorpe RJ. The Association Between Happiness and Self-Rated Physical Health of African American Men: A Population-Based Cross-Sectional Study. Am J Mens Health [Internet]. 2018 Jun 27;12(5):1615-20. Available from: https://doi.org/10.1177/1557988318780844

35. Kim J, Song Y, Kim T, Park K. Predictors of happiness among older Korean women living alone. Geriatr Gerontol Int [Internet]. 2019 Apr 1;19(4):352-6. Available from: https://doi.org/10.1111/ggi.13615

36. Sneade M, Furnham A. Hand Grip Strength and Self-Perceptions of Physical Attractiveness and Psychological Well-Being. Evol Psychol Sci [Internet]. 2016 Jun 20 [cited 2020 Aug 24];2(2):123-8. Available from: https://link.springer.com/article/10.1007/s40806-016-0042-z

37. Higuchi M, Suzuki K, Ashida T, Kondo N, Kondo K. Social Support and Access to Health Care Among Older People in Japan: Japan Gerontological Evaluation Study (JAGES). Asia-Pacific J Public Heal. 2018;30(5):425-36.

38. Şahin DS, Özer Ö, Yanardağ MZ. Perceived social support, quality of life and satisfaction with life in elderly people. Educ Gerontol. 2019;45(1):69-77.

39. del-Pino-Casado R, Frías-Osuna A, Palomino-Moral PA, Ruzafa-Martínez M, Ramos-Morcillo AJ. Social support and subjective burden in caregivers of adults and older adults: A meta-analysis. PLoS One. 2018;13(1):1-18.

40. Whangmahaporn P, Simmonds P, Whangmahaporn B. Factors Affecting Quality of Life of the Elderly in Thailand. SSRN Electron J [Internet]. 2018 Dec 26 [cited 2020 Oct 18]; Available from: https://papers.ssrn.com/abstract=3304833

41. Nanthamongkolchai S, Tuntichaivanit Msc C, Munsawaengsub C, Charupoonphol P. Factors Influencing Life Happiness among Elderly Female in Rayong Province, Thailand [Internet]. Vol. 92, J Med Assoc Thai. 2009 [cited 2020 Oct 22]. Available from: http://www.mat.or.th/journal

42. Motalebi SA, Ahmadi A, Soleimani MA, Pahlevan Sharif S. Association Between Perceived Social Support and Happiness Among Community-dwelling Elderly Adult. J Qazvin Univ Med Sci [Internet]. [cited 2020 Oct 22];23. Available from: https://doi.org/10.32598/JQUMS.23.4.320

43. Lara R, Vázquez ML, Ogallar A, Godoy-Izquierdo D. Psychosocial Resources for Hedonic Balance, Life Satisfaction and Happiness in the Elderly: A Path Analysis. Int J Environ Res Public Health [Internet]. 2020 Aug 6 [cited 2020 Oct 22];17(16):5684. Available from: https://www.mdpi.com/1660$4601 / 17 / 16 / 5684$

44. Bøen H, Dalgard OS, Bjertness E. The importance of social support in the associations between psychological distress and somatic health problems and socio-economic factors among older adults 
living at home: a cross sectional study. BMC Geriatr [Internet]. 2012 Dec 8 [cited 2020 Oct 23];12(1):27. Available from: http://bmcgeriatr.biomedcentral.com/articles/10.1186/1471-2318-1227

45. Kahlbaugh P, Huffman L. Personality, Emotional Qualities of Leisure, and Subjective Well-Being in the Elderly. Int J Aging Hum Dev. 2017;85(2):164-84.

\section{Supplementary Files}

This is a list of supplementary files associated with this preprint. Click to download.

- EnglishVersionQuestionnaire.docx 